\title{
Phonotactic Properties of Turkish Folk Music Phonetic Notation System/TFMPNS: Urfa Region Sample
}

\author{
Gonca Demir \\ Istanbul Technical University Turkish Music State Conservatory, Vocal Performance Department, Istanbul, Turkey
}

Email address:

gnc.dmr@windowslive.com

To cite this article:

Gonca Demir. Phonotactic Properties of Turkish Folk Music Phonetic Notation System/TFMPNS: Urfa Region Sample. Humanities and Social Sciences. Vol. 3, No. 4, 2015, pp. 125-132. doi: 10.11648/j.hss.20150304.11

\begin{abstract}
Turkish folk music has a priviliged place in music types due to regional dialect varieties. The future of Turkish folk music depends on protection of its attitude originating from dialect differences and its resistance against change. Turkish folk music regional dialect properties are transcripted by Turkish Linguistic Institiution Transcription Signs/TLITS depending on linguistic laws in axis of phonetics, morphology and parole existence. On the other hand, depending on musicological laws, regional dialect properties of Turkish folk music which is a verbal/artistic performance type structured in axis of linguistic approaches in ethnomusicology-performance/display theory are also transcripted by Turkish Linguistic Institution Transcription Signs/TLITS. It is determined and approved by linguistic/musicology source and authotrities that this reality which is also present in other world languages can be transferred to notation and vocalized again and again in accordance with its original through International Phonetic Alphabet/IPA existence and usability of which have been registered by local and universal standards through the notification that will be submitted. In order to initiate an application parallel to applications in national/international platforms a suggestion was made under the scope of ITU SBE TMP Post Graduation Program thesis, it will be developed under the scope of ITU SBE MJT Doctorate Program thesis, therefore Turkish Folk Music Phonetic Notation System/TFMPNS based on Turkish Linguistic Insitution Transcription Signs/TLITS and International Phonetic Alphabet/IPA sounds in axis of linguistics/morphology measures together with local/universal attachments will be introduced; the conveying and adaptation processes of phonotactic properties (defined as a field of science examining the voices that may and may not be placed respectively in a language, phonology/voice combination/voice coalescence rules) to Turkish Folk Music Phonetic Notation System/TFMPNS will be realized. Gele Gele Geldim Bir Kara Dasa folk music text which is one of the 128 melodious poetical literature examples transcripted by Urfa/Kerkük/Tallâfer Dialects Turkish Linguistic Insitution Transcription Signs/UKTD TLITS and musics recorded live in music assemblies between years 1967-1987 and phonograph records were selected as sample material (together with voice record compiled from a source person who is expert in the regional music and universal correlations) that will be examined by phonotactic theory/analysis method according to scientific compilation rules. Besides, detailed emphasize will be made on Turkish Folk Music Phonetic Notation System of Phonotactic Awareness Skill Development Processes/TFMPNS PASDP-Turkish Folk Music Phonetic Notation System of Phonotactic Therapy Applications/TFMPNS PTA-Turkish Folk Music Phonetic Notation System of Phonotactic Probability Calculator Database/TFMPNS PPCD.
\end{abstract}

Keywords: Phonetic, Phonotactic, Turkish Folk Music

\section{Turkish Folk Music Phonetic Notation System Phonotactical Awareness Skills Development Processes/TFMPNS PASDP}

Phonotactic features of Urfa Turkish folk music, keeping their existence in the axis of sound information criteria in performance and theoretical infrastructure of local language properties: $\breve{1}$, ŭ, ü and ô (narrow, semi-narrow o), è (close e) and ì (long i) sounds which are the narrow, flat, half-round and closed shapes of $i, u$, ü sounds close to e were determined in addition to a, e, 1, i, o, ö, u, ü sounds located in Turkish in Turkey. In terms of continuity neither short nor the long vowels (except the words 'āşı k and yār) are in the normal length. Vowels belong to the words which are entered to the language from Arabic and Persian are often normalized: such as hammām> hemam "hamam" etc. With long i resulting from the 
reduction or adjustment of sound, long $\mathrm{i}$ in the taken words located in the poems written in divan poetry form retain their lengths during the usage. In Turkish all vowels except 1 sound have normal lengths. This property of Turkish effects the taken words too. In Urfa's dialects just like in all East Anatolian dialects, long vowels from the taken words are shortened systematically and turned to the normal length vowels. For example mahmūr $>$ mahmur "sleepy, silly" etc. As a result of the transformation of second singular person suffix $n$ into y in Urfa dialect and sometimes completely removing even this y sound, it is seen that $\mathrm{i}$ sound at the end of a word is voiced in a long tone: For instance ettin>ettiy>ettī "ettin" etc. o, ö vowels in Urfa dialect are located only on the first syllable in accordance with the Turkish general rule. It is seen that -yor, continuous time suffix which is never be used in Urfa dialect, started to be used in both form by breaking the general rule: like gidiyor, gídiy "gidiyor" etc. In addition to the sounds b, c, ç, d, f, g, h, j, $\mathrm{k}, \mathrm{l}, \mathrm{m}, \mathrm{n}, \mathrm{p}, \mathrm{r}, \mathrm{s}, \mathrm{s}, \mathrm{t}, \mathrm{v}, \mathrm{y}, \mathrm{z}$ in Turkey Turkish written language, $\dot{\mathrm{g}}$, $\mathrm{h}, \mathrm{h}, \mathrm{k}$, , '(ayın) and ' (hemze) sounds were determined. There is no $\mathrm{j}$ sound in Urfa dialect. Just like in Old Anatolian Turkish, this sound is only seen in the taken words. Only the word vicdan $>$ vijdan formed as a result of the change $c>j$ in local folk music compilation is detected. Depending on the general sound rules of Turkish, c, $\breve{g}, 1, \mathrm{~m}$, v sounds are located among the sounds which are not found in the beginning of the words and $b$, c, d, g, $\dot{g}$ at the end of a word or syllables. On the contrary to the general sound rules of Turkish, b, d, g sounds are seen in the foreign words like kebāb>kebab "kebap", etc. c and g are seen at the end of both Turkish words like hem dag $>$ dag "yara" etc. and taken words like harāc $>$ herac "haraç" etc. Sound $\dot{g}$ has been used at the end of a word and syllables in old Turkish and it is a sound found today in some Turkish dialect except Western Turkish. This situation is not a rule which has finalized and used widely in Urfa dialect. In the taken words which is ended with toned consonants, it is seen that these sounds are untoned, for example makṣūd $>$ mahsut "maksat" etc. In the sound lyrics belong to Urfa region, $\tilde{n}$ "nazal n" nasal consonant ve $\mathrm{j}$ sound are not found but ñ sound transform into ng, g, n, v, y sounds: as in yeñi>yëngī "yeni”" etc.

It is reported that Phonotactical features existing in the axis of shape information in theoretical and practical background of local dialect properties of Urfa Turkish folk music: sound changes: vowel changes (thinning of thick vowels-thickening of thin vowels-rounding of flat vowels-flattening of round vowels-narrowing of wide vowels-widening of narrow vowels-transformation of narrow/round vowels into semi narrow/round vowels), consonant changes (toning/un-toning/ continuing/discontinuing/some changes among continuous consonants/other changes), sound events (affinity/consonant formation/dropping/twinning/formation/falling/merging/bumpi ng/narrowing of middle syllable/changing location/syllable fall/shortenings in the names), harmony (vowel harmony/consonant harmony-vowel/consonant harmony).

Phonotactical features existing in the axis of shape information in theoretical and practical background of local dialect properties of Urfa Turkish folk music: Arabic-Persian translations, metaphorical meanings, shape and usage types of local words located in 128 song text belong to Urfa region, even though they are removed from Turkey Turkish written language, they are used in Urfa dialect widely are given under the title index and dictionary, respectively [1] (refer with: Table 1).

Table 1. Turkish Folk Music Phonetic Notation System Phonotactical Awareness Skills Development Processes/TFMPNS PASDP developed in the axis of local/universal structural/generative/transformation linguistic theories, linguistic/written science/rhetorical/phonological approaches in ethnomusicology, phonetic/phonetic-morphological info/syntactic-sound assets/the lexical criteria.

\begin{tabular}{|c|c|c|c|}
\hline \multicolumn{4}{|c|}{ 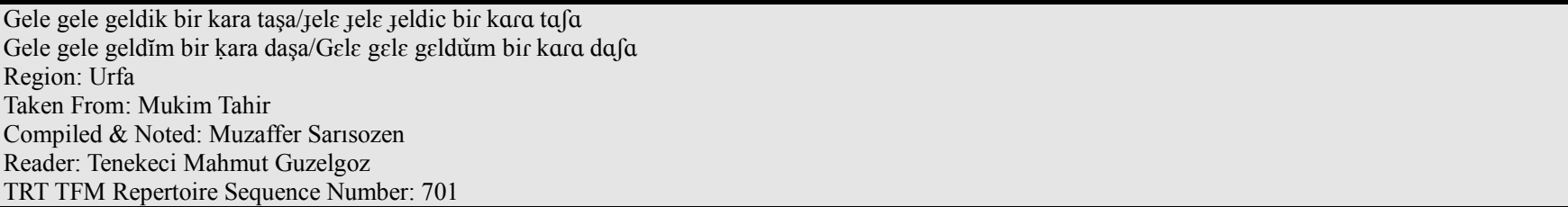 } \\
\hline Standard Turkey Turkish/STT & International Phonetic Alphabet/IPA & $\begin{array}{l}\text { Turkish Language Institution } \\
\text { Transcription Signs/TLITS }\end{array}$ & International Phonetic Alphabet/IPA \\
\hline Gele gele geldik bir kara taşa & Jel $\varepsilon$ Jel $\varepsilon$ Jeldic bir kara ta $\int a$ & Gele gele geldı̌m bir ḳara daşa & Gele gele geldǔım bir kara da $\int a$ \\
\hline $\begin{array}{l}\text { Yazılanlar gelir sağ olan başa aman } \\
\text { efendim }\end{array}$ & $\begin{array}{l}\text { jazuratantar Jelir sa: ołan ba } \int a \text { aman } \\
\text { efendim }\end{array}$ & $\begin{array}{l}\text { Yazılanlar gelĭr saġ olan başa aman } \\
\text { efendīm }\end{array}$ & 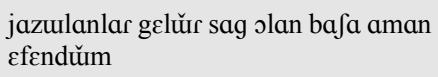 \\
\hline Bizi hasret koyar kavim kardaşa & bizi hasret kojar kavim karda $\int a$ & Bǐzĭ ḥesret ḳoydı ḳavım ḳardaşa & Bǔzǔ ḩعsret kojdu kavum kardafa \\
\hline $\begin{array}{l}\text { Bir ayrllık bir yoksulluk bir ölüm } \\
\text { aman efendim }\end{array}$ & $\begin{array}{l}\text { bir ajrułuuk bir joksułtuk bir ølym } \\
\text { aman efendim }\end{array}$ & $\begin{array}{l}\text { Bir ayrılıh bir yohssıllıh bir ölüm } \\
\text { aman efendĭm }\end{array}$ & 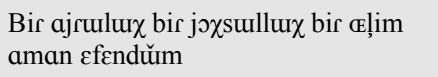 \\
\hline Nice sultanlart tahttan indirir & nidze sultanłaru tahttan indiris & Nice Sülèymanları taḩtan èndǐrĭr & 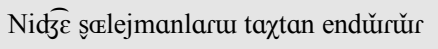 \\
\hline Niceleri dönmez yola gönderir & nidzeleri dønmez_joła Jønderir & Nicesĭnı̆ dönmez èle gönderĭr & 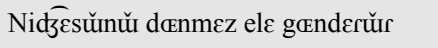 \\
\hline $\begin{array}{l}\text { Bir ayrllık bir yoksulluk bir ölüm } \\
\text { aman efendim }\end{array}$ & $\begin{array}{l}\text { bir ajrułuk bir joksułtuk bir ølym } \\
\text { aman efendim }\end{array}$ & $\begin{array}{l}\text { Bir ayrılıh̆ bir yohsılllıh bir ölüm } \\
\text { aman efendĭm }\end{array}$ & 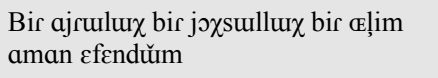 \\
\hline $\begin{array}{l}\text { Note } 1 \text {. Transcription systems in } \\
\text { Anatolia dialect researches: } \\
\text { transcripted with Standard Turkey } \\
\text { Turkish/STT in the axis of standard }\end{array}$ & $\begin{array}{l}\text { Note 2. IPA Turca: IPA provisions } \\
\text { and sound description [4] of the } \\
\text { letters in Turkish alphabet in } \\
\text { Rule-Based Turkish Phonetic }\end{array}$ & $\begin{array}{l}\text { Note } 3 \text {. Linguistic approaches in } \\
\text { ethnomusicology [8]: phonetic } \\
\text { writing usage in data recording in } \\
\text { musicology: necessity of dialect }\end{array}$ & $\begin{array}{l}\text { Note } 4 \text {. International Phonetic } \\
\text { Alphabet/IPA usage in dialect } \\
\text { researches of Turkish language: } \\
\text { written dialect texts in Turkey by }\end{array}$ \\
\hline
\end{tabular}




\begin{tabular}{|c|c|c|c|}
\hline $\begin{array}{l}\text { writing/transcription/variation } \\
\text { method [2]. }\end{array}$ & $\begin{array}{l}\text { Converter Program/RBTPCP [3]. } \\
\text { Turkey Turkish Pronunciation } \\
\text { Dictionary/TTPD phonology } \\
\text { ABC's: transcripted with } \\
\text { International Phonetic Alphabet/IPA } \\
\text { [6] by the IPA correspondences of } \\
\text { vowel and consonants [5]. }\end{array}$ & $\begin{array}{l}\text { documentation in linguistic and } \\
\text { musicological axis: } \\
\text { Urfa/Kerkuk/Tallafer Dialects } \\
\text { Turkish Language Institution } \\
\text { Transcription Signs/UKTD TLITS } \\
\text { in the axis of phonetic notation } \\
\text { method [7] of local dialect features } \\
\text { of Turkish folk music: transcripted } \\
\text { with vowels-consonants-distinctive } \\
\text { signs [1]. }\end{array}$ & $\begin{array}{l}\text { using IPA (TDK-IPA) provisions of } \\
\text { transcription signs are transcripted } \\
\text { with Standard Turkey Turkish/STT- } \\
\text { Turkish Language Institution } \\
\text { Transcription Signs/TLITS- } \\
\text { International Phonetic Alphabet/IPA. }\end{array}$ \\
\hline
\end{tabular}

\section{Turkish Folk Music Phonetic Notation System Phonetic Therapy Applications/TFMPNS PTA}

In order to eliminate possible generative/cognitive/educational/doctrinal errors/limitations/biases [9] based on articulation/acoustical-perceptual-cognitive factors/trends in Turkish Folk Music Phonetic Notation System Phonotactical Therapy Applications/TFMPNS PTA performed together with local/universal correlation in the axis of Turkish Folk Music Phonetic Notation System Phonotactical Awareness Skills Development Processes/TFMPNS PASDP with the phonetic therapy method [10] in the level of listening/narrative/transmissions, it is required to complete the construction and development processes of alphabet/sound/dictionary/product database.

Turkish Folk Music Phonetic Notation System Alphabet Database/TFMPNS AD: transcription system of Turkish Language Institution/TLI dialect researches [11], transcript in dialect studies [12], vowel and consonant changes of Anatolia dialects [42], Urfa/Kerkuk/Tallafer Dialects Turkish Language Institution Transcript Signs/UKTD TLITS [1], IPA provisions of the words in Turkish alphabets and TDK-IPA provisions of voice descriptions-transcription signs [4], phonology ABCs of Turkey Turkish Pronunciation Dictionary/TTPD: IPA provisions of vowels and consonants
[6], extra-IPA symbols for irregular speaking [14], IPA number table [15], IPA unicode character codes [16], IPA X-SAMPA equivalency table [17].

Turkish Folk Music Phonetic Notation System Sound Database/TFMPNS SD: International Phonetic Alphabet/IPA sound records [18], International Phonetic Alphabet/IPA Turkish vowel/consonants tables sound records [18], Turkish Language Institution Turkish Audio Dictionary/TLI TAD [19], 128 pieces of Turkish folk music texts sound records transcripted with the Urfa/Kerkuk/Tallafer Dialects Turkish Language Institution Transcript Signs/UKTD TLITS [20].

Turkish Folk Music Phonetic Notation System Dictionary Database/TFMPNS DD: Turkish Language Institution Current Turkish Dictionary/TLI CTD [21], Turkish Language Institution Turkish Audio Dictionary/TLI TAD [19], Turkish Language Institution Big Turkish Dictionary/TLI BTD [22], Turkish Language Institution Search Dictionary/TLI SD [23], Turkish Language Institution Turkey Turkish Dialects Dictionary/TLI TTDD [24], Turkish Language Institution Folk Dialects Compilation Dictionary in Turkey/TLI CDFDT, Turkey Turkish Pronunciation Dictionary/TTPD [5], Urfa/Kerkuk/Tallafer Dialects Index and Dictionary/UKTD ID [1].

Turkish Folk Music Phonetic Notation System Works Database/TFMPNS WD; 128 pieces of Turkish folk music texts transcripted with the Urfa/Kerkuk/Tallafer Dialects Turkish Language Institution Transcription Signs/UKTD TLITS [1], IPA Turca: Rule-Based Turkish Phonetic Converter Program/RBTPCP [3] (refer with: Fig. 1, Table 2).

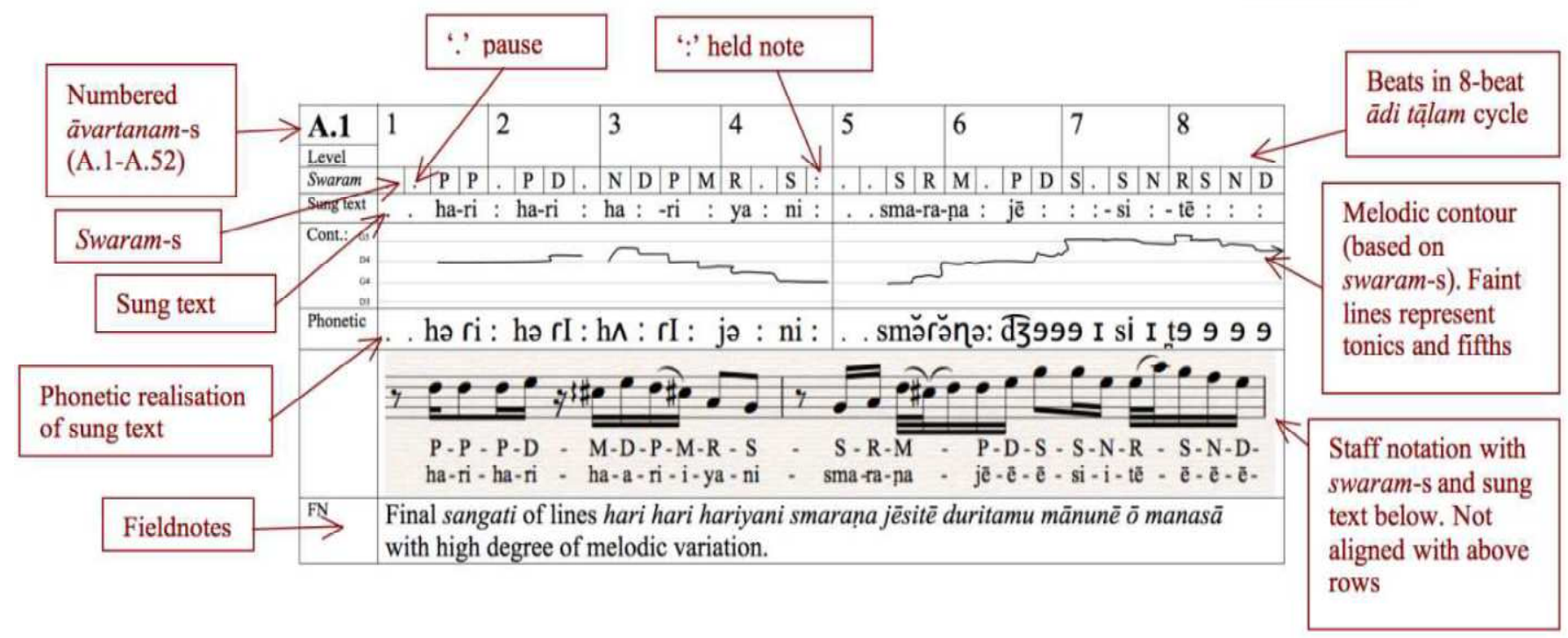

Fig. 1. Musicolinguistic artistry of niraval in Carnatic vocal music: musicolinguistic graph/chart/diagram samples [30]. 
Table 2. Turkish Folk Music Phonetic Notation Systems Phonotactical Therapy Applications/TFMPNS PTA performed in the axis of the Turkish Folk Music Phonetic Notation System Phonotactical Awareness Skills Development Processes/TFMPNS PASDP: musicolinguistic artistry graph/chart/diagram samples.

\begin{tabular}{|c|c|c|c|}
\hline $\begin{array}{l}\text { Gele gele geldik bir kara taşa/Je } \\
\text { Gele gele geldĭm bir ḳara daşa/ } \\
\text { Region: Urfa } \\
\text { Taken From: Mukim Tahir } \\
\text { Compiled \& Noted: Muzaffer S } \\
\text { Reader: Tenekeci Mahmut Guz } \\
\text { TRT TFM Repertoire Sequence }\end{array}$ & $\begin{array}{l}\text { Jeldic bir kara tafa } \\
\text { ele geldǔm bir kara dafa } \\
\text { en } \\
\text { ber: } 701\end{array}$ & & \\
\hline Standard Turkey Turkish/STT & International Phonetic Alphabet/IPA & $\begin{array}{l}\text { Turkish Language Institution } \\
\text { Transcription Signs/TLITS }\end{array}$ & International Phonetic Alphabet/IPA \\
\hline Gele gele geldik bir kara taşa & Jel $\varepsilon$ Jel $\varepsilon$ Jeldic bir kara ta $\int a$ & Gele gele geldǐm bir ḳara daşa & Gele gele geldǔm bir kara da $\int a$ \\
\hline $\begin{array}{l}\text { Note } 1 \text { Sound information c } \\
\text { Turkish/STT }>\text { International Pho } \\
\text { (closed) }>[\varepsilon] \text { wide, flat, pre-tong } \\
\text { voice explosive, tongue tip is o } \\
\text { voice, explosive tongue-back pa } \\
\text { voice, single matrix, tongue ti } \\
\text { Urfa/Kerkuk/Talaffer Dialects } \\
\text { vowel between } \mathrm{i} / \mathrm{e}>[\text { ǔt] very sh } \\
\text { thick vowels }>[\mathrm{k}] \text { voiceless, rear }\end{array}$ & $\begin{array}{l}\text { existing in the theory and applica } \\
\text { Alphabet/IPA [a] wide, flat, soft palate } \\
\text { pen)-[i] narrow, flat, odile (open) }>[1] /[\mathrm{i} \\
\text { voiceless, explosive, back palate }>[\mathrm{c}] \mathrm{c} \\
\text { front)-[1]>[1] tone, gum, lateral fluent-[n } \\
\text { [ [Y] voiceless, fricative-[s] }>\left[\int\right] \text { voice } \\
\text { h Language Institution Transcript Sign } \\
\text { k] a back palate consonant thicker, exp } \\
\text { e, explosive. }\end{array}$ & $\begin{array}{l}\text { on background of I. line of Turkis } \\
\text { (predorsal) }>[\alpha] \text { wide, flat, back palate } \\
\text { narrow, flat, pre-tongue (closed)-[b]> } \\
\text { imes, front palate, explosive- }[\mathrm{g}] \text { tone, } \\
]>[\mathrm{m}] \text { tone, double lip, nasal initial- }[\mathrm{r}] \\
\text { ess, fricative, tongue-soft palate- }[\mathrm{t}]>[\mathrm{t} \\
\text { /UKTD TLITS }>\text { International Phonetic } \\
\text { osive and made further back than norm }\end{array}$ & $\begin{array}{l}\text { folk music text: Standard Turkey } \\
\text { post dorsal)-[e] wide, flat, pre-tongue } \\
\text { o] voice, explosive, double-lip-[d] }>[\mathrm{d}] \\
\text { ront palate-mid-tongue, explosive }>[\mathrm{J}] \\
\text { oice, multi-matrix, tongue tip-gum }>[\mathrm{r}] \\
\text { voiceless, explosive, tip end is out. } \\
\text { Alphabet/IPA: [1] short unaccented, a } \\
\text { l k constructing syllables with thin or }\end{array}$ \\
\hline
\end{tabular}

\section{CVCV CVCVCVCCVCCVCCVCV CVCVCVCVCVCCVCCVCCVCV CVCV CVCV CVCCVC CVC CVCV CVCV CVCCVC CVC CVCV CVCV CVCV CVCV CVCV CVCV}

Note 2. Form information criteria existing in theoretical and practical background in I. line of the Turkish folk music text: $\mathrm{V} / \mathrm{C}$ analysis [26]: $\mathrm{V}=$ vowel (vowel letter), $\mathrm{C}=$ consonant (consonant letter). When $\mathrm{V} / \mathrm{C}$ analyzing method is applied to all lines of the folk music text, differences in the axis of sound/syllable/word/sentence orders may arise.

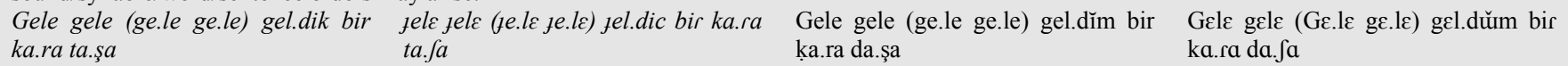

Note 3. Syntactic criteria of sound/syllable/word/sentence existing in theoretical and practical background of the I. line of the Turkish folk music text: prosodic phonotactical analysis [27]: (.) = represents the syllabic segmentation points. When prosodic phonotactical analysis method is applied to all lines of the folk music text, differences may arise in the acoustic/syllabic/word/sentential partitioning/impact points axis in terms of linguistic/rhythmic-music scientific/melodic prosody overlap rules.

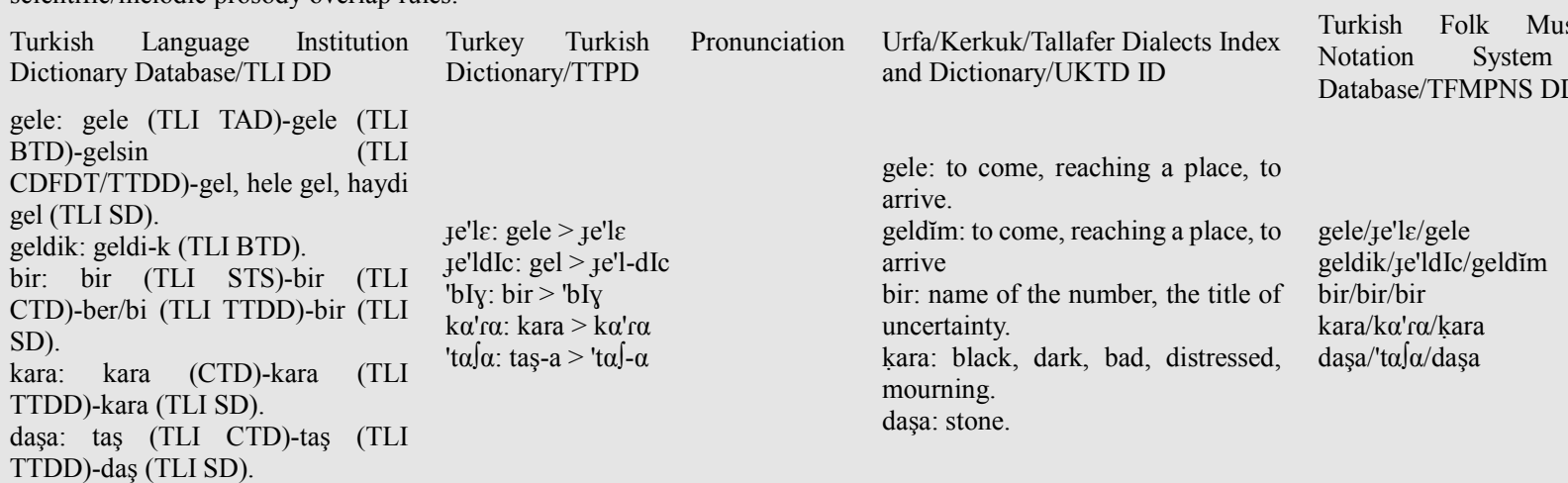

Note 4. Word existence criteria existing in the theoretical and practical background of I. line of the Turkish folk music text: Turkish Language Institution Current Turkish Dictionary/TLI CTD [21], Turkish Language Institution Turkish Audio Dictionary/TLI TAD [19], Turkish Language Institution Big Turkish Dictionary/TLI BTD [22], Turkish Language Institution Scanning Dictionary/TLI SD [23], Turkish Language Institution Turkey Turkish Dialect Dictionary/TLI TTDD [24], Turkish Language Institution Compilation Dictionary Folk Dialects in Turkey/TLI CDFDT [25], Urfa/Kerkuk/Tallafer Dialects Index and Dictionary/UKTD ID [1], Turkey Turkish Pronunciation Dictionary/TTPD [5], Turkish Folk Music Phonetic Notation System Dictionary Database/TFMPNS DD.

\section{Turkish Folk Music Phonetic Notation System Phonotactical Probability Calculator Database/TFMPNS PPCD}

Developing the skills like phonotactical possibilities, limitations, usages, tips, performance, memory, knowledge etc. [28] existing in the level of the utilities of phonemic/cognitive/motor approaches-phonological/shape informational/sound existential structured together with local/universal additions in the local/universal phonology/phonetic rules axis, by providing the organic transitivity among the music-linguistic properties structured in the language science approaches in ethnomusicology in musicological plane with phonotactical properties [29] structured in phonotactical theory axis in linguistic plane, creating music-linguistic graph/chart/diagram samples [30], in order to determine the phonetic/phonemic/allophonic transcription differences with the range of linguistic/literary-musicological/practical [31], it is necessary 
to perform the transfer/adaptation processes of Turkish Folk Music Phonetic Notation System Phonotactical Probability Calculator Database/TFMPNS PPCD in the axis of phonotactic probability analysis method [39] parallel to databases like BLICK: a phonotactic probability calculator [32]-IphOD: irvine phonotactic online dictionary [33]-UCLA phonetics lab archive [34]-UCLA: manual: phonotactic learning program [35]-PPC: phonotactic probability calculator [36]-NP extension: B\&B phonotactics [37]-ANU world phonotactic database [38] existing in the local/universal literature.

In order to provide numerical/proportional feedback documentation like performing the statistical analyses, determination of the usage ratio of phonotactical features existing in the level of phonological/structural/word scientific criteria in the theoretical/practical background of characteristic work samples of Turkish folk music determined within the range of phonetic notation of regional dialect features [7] of Turkish folk music structured in the axis of the language/music relation together with local/universal correlation, a general table can be made via Turkish Folk Music Phonetic Notation System Phonotactical Probability Calculator Database/TFMPNS PPCD.

Turkish Folk Music Phonetic Notation System Phonotactical Probability Calculator Database/THMFNS PPCD structured with the local correlations in the axis of local structural/generative/transformational linguistic theories-linguistic/writing scientific/phonological/ rhetorical in ethnomusicology sound knowledge/phonetic-morphological/syntactic-word

THE INTERNATIONAL PHONETIC ALPHABET (revised to 2005)

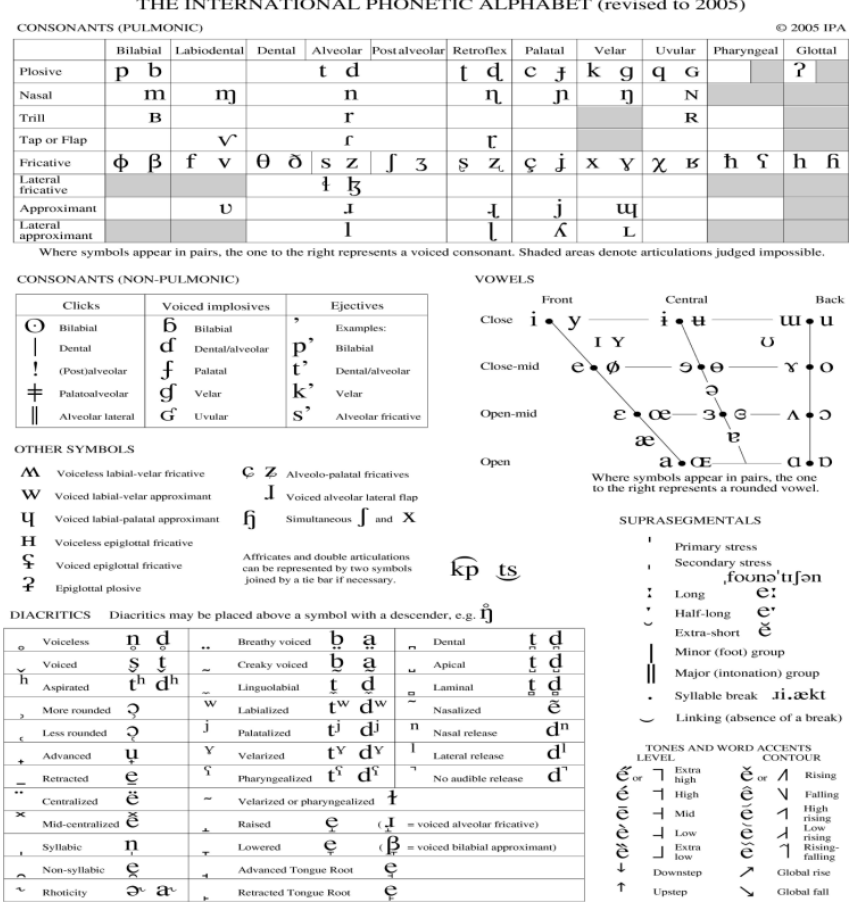

assets/lexical extent: IPA provisions and sound definitions of the letters in Turkish alphabets IPA provisions of transcript signs [4], Urfa/Kerkuk/Tallafer Dialects Turkish Language Institution Transcript Sings/UKTD TLITS vowel/consonant distinctive signs [1], IPA Turca: Rule Based Turkish Phonetic Translator Program/RBTPTP character codes [3], Turkey Turkish Pronunciation Dictionary/TTPD phonology ABCs: Standard Tukey Turkish/STT IPA provisions of vowels and consonants [5], UCLA phonetics lab archive/Turkish language section [34].

Turkish Folk Music Phonetic Notation System Phonotactical Probability Calculator Database/THMFNS PPCD structured with the universal correlations in the axis of universal structural/generative/transformational linguistic theories, linguistic/written scientific, rhetorical/phonological approaches in ethnomusicology-sound information/phonetic-figure information/syntactic-word assets/lexical extent: International Phonetic Alphabet/IPA [40], extra-IPA symbols for irregular speech [14], IPA number table [15], IPA X-SAMPA equivalency table [17], International Phonetic Alphabet/IPA Turkish vowel/consonant letter tables [6], IPA unicode character code charts [16], IPA fonts (SIL Encore IPA and SIL IPA93 fonts (doulos/sophia/manuscript fonts: base characters/diacritics/tone and punctuation)-phonetic fonts for macintosh/windows-adobe fonts for macintosh/windows-the four stone phonetic fonts in GIF form (stone sans/stone sans alternate/stone serif/stone serif alternate)-rogers fonts (IPAPhon) for macintosh/windows-phonetic fonts for TeX/LaTeX etc. [41] (refer with: Fig. 2).

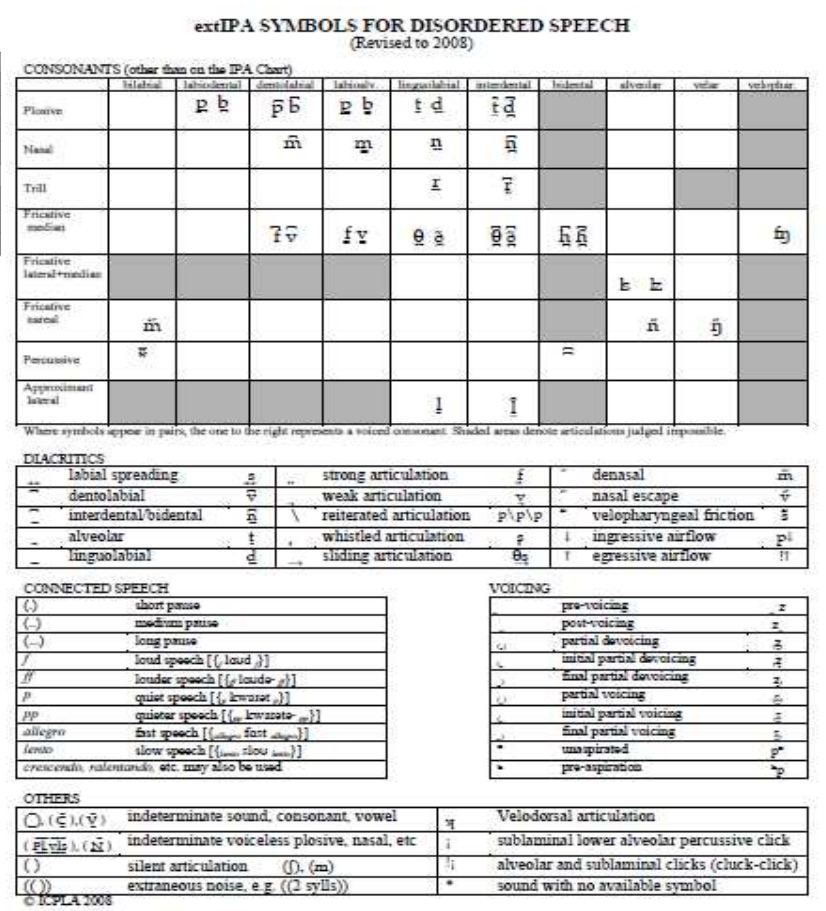



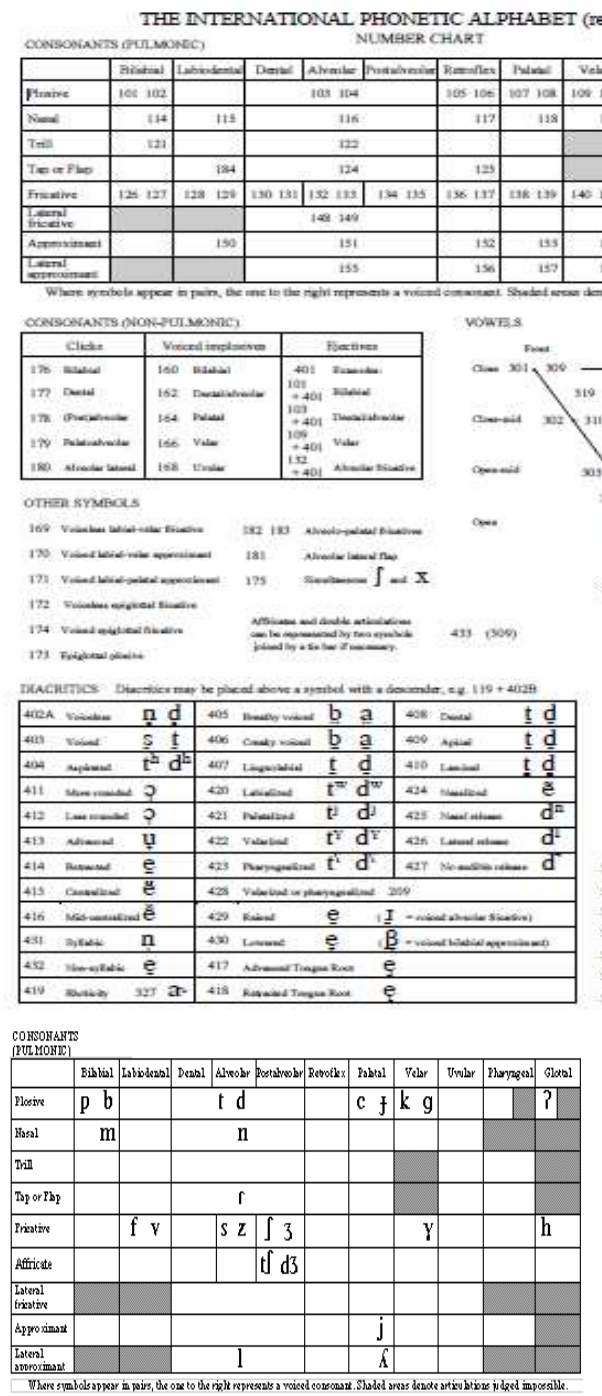
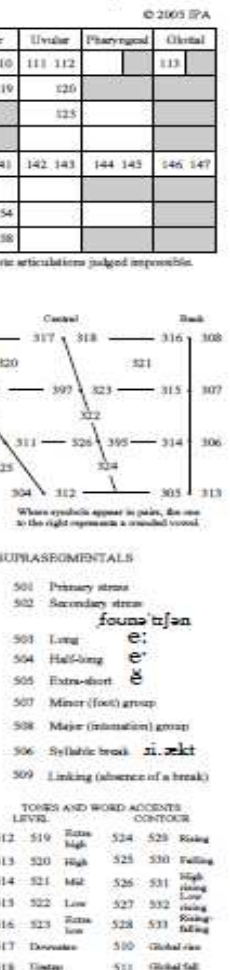

NOWELS

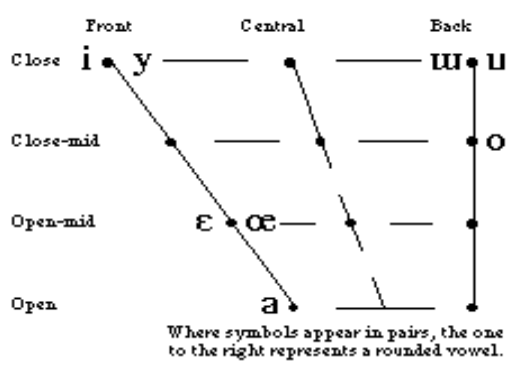

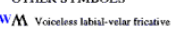

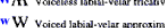

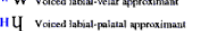
Eried
THE INTERNATIONAL PHONETIC ALPHABET (revised to 1993)

\begin{tabular}{|c|c|c|c|c|c|c|c|c|c|c|c|}
\hline & Bilibtal & Latiodenta & \begin{tabular}{|l|l|} 
Destal \\
\end{tabular} & Aveolater & Potallivelatar & Retroflex & Pulatal & Velat & Uvolata & Plaryogeal & Glisatat \\
\hline Plosive & $\mathrm{p}_{\mathrm{p}} \mathrm{b}$ & & & $t_{d}^{d}$ & & $t, d$ & c c f & $\mathrm{kr}_{\mathrm{k}} \mathrm{g}$ & $\mathrm{q} G$ & & $?$ \\
\hline Nasal & $\mathrm{m}$ & $\mathrm{m}$ & & n & & $n$ & $\mathrm{n}_{\mathrm{s}}$ & n & $\mathbf{N}$ & & \\
\hline Trill & ${ }_{B}^{B}$ & & & $r$ & & & & 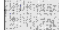 & ${ }_{\mathrm{R}}^{\mathrm{R}}$ & & \\
\hline Tap or Flap & & & & $r_{4}$ & & $r_{r}$ & & 5 & & & 5 \\
\hline Fricative & $\phi_{\mathrm{p}} \beta_{\mathrm{B}}$ & $f \quad v$ & $\theta_{\mathrm{T}} \partial$ & $\begin{array}{ll}s_{s} & z \\
z\end{array}$ & $\int_{\mathrm{s}} 3 \mathrm{z}$ & s. & $c_{j} j$ & ${ }_{x} x$ & $\chi_{\mathrm{X}}^{\mathrm{K}}$ & $\mathrm{h}_{\mathrm{x}} \mathrm{f}_{\mathrm{z}}$ & $h_{h}$ \\
\hline $\begin{array}{l}\text { Lateral } \\
\text { fricative }\end{array}$ & & Hest & & $1_{k} 3$ & & & & & & & \\
\hline Appoximarte & & $\underset{P \text { (orv }}{U}$ & & $I_{r}$ & & $\mu^{t}$ & ${ }_{\mathrm{j}}^{\mathrm{j}}$ & $m^{u}$ & & & \\
\hline $\begin{array}{l}\text { Lateral } \\
\text { approximant }\end{array}$ & & (1) & & 1 & & ll & ${ }_{1} K$ & ${ }^{L}$ & & & \\
\hline
\end{tabular}

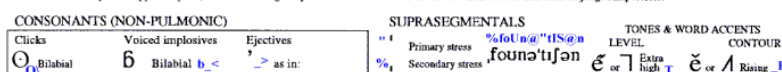

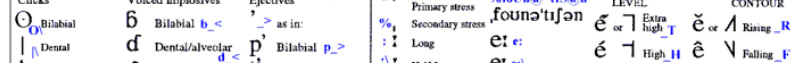

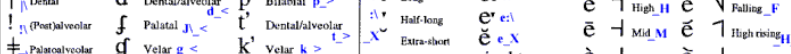

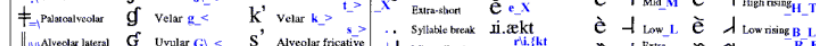

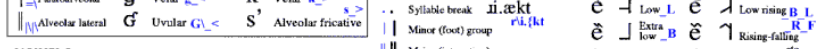
VOWELS.S

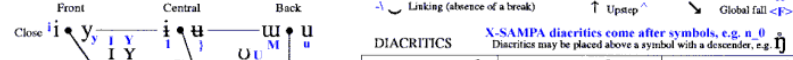

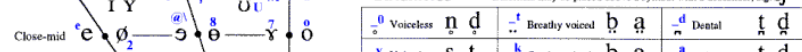

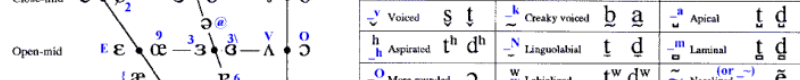

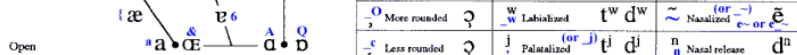

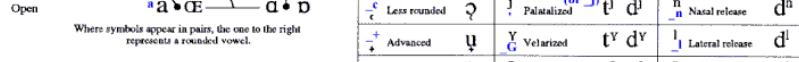

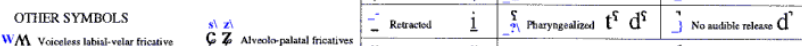

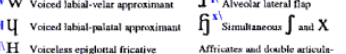

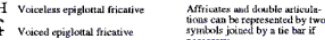
$\underset{k \rightarrow p}{\operatorname{kp}_{i}} \underset{t s}{T}$ Pulmonic Consonolits

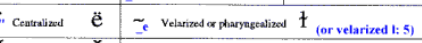

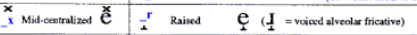

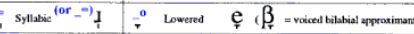

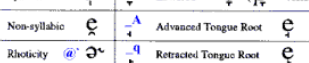

\begin{tabular}{|c|c|c|}
\hline 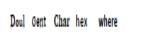 & nam & Prat definition \\
\hline 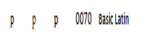 & 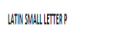 & wiblbibi pbias \\
\hline 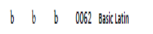 & 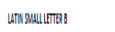 & whibibipsile \\
\hline 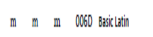 & 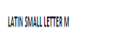 & whibdian nal \\
\hline 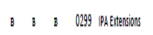 & 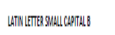 & wdibibiat tril \\
\hline i $\$ \quad 078$ patitrions & 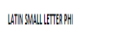 & 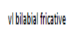 \\
\hline 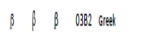 & 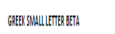 & whibibil thatitin \\
\hline 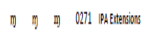 & 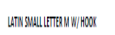 & 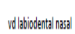 \\
\hline 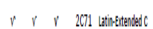 & 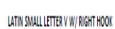 & 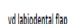 \\
\hline
\end{tabular}

Fig. 2. Turkish Folk Music Phonetic Notation System Phonotactical Probability Calculator Database/TFMPNS PPCD graph/chart/diagram samples structured with the local/universal correlations in the axis of local/universal phonology/phonetic rules.

\section{Summary}

Language which involves a vocal expression in styles changing from society to society with semantic content and which is also a human experience is a communication area as well. Vocal expression which denotes people's skill of communication through vocal indicator is articulated as distinctive and sequential voice units which exist in every language in specific quantity and with their attributions whose reciprocal correlations vary from a language to another. Phonetic awareness which includes rules determining paradigmatic/syntagmatic relations of speaking sounds in a language and analyzes speaking sounds in the sense of functions in communication was defined as gaining awareness to speaking sounds, being aware of sounds and having the skill of manipulating sounds. It was emphasized by dialectologists in linguistic axis that language which was accepted to be a cultural value including aesthetical content and indicators of basic characteristics of societies rather than being a product simply involves various dialects, this content subsists in every language and thereby in the music of each language together with traditional relations, correct pronunciation of these different speeches can be achieved through usage and articulation of International Phonetic Alphabet/IPA sounds which contribute to the development of melodic memory with its evocative effect; and it was emphasized by musicologists in musicological axis that how far usage of International Phonetic Alphabet/IPA within vocal music would direct practical behaviours and performances of musicians directly in the process of adaptation, reasons of level/detailedness of perceptibility/intelligibility of International Phonetic Alphabet/IPA symbols by musicolog.

International Phonetic Alphabet/IPA is a type of standard alphabet which is composed of signs and symbols in order to put sound values on paper in international standard, code speaking sounds in every language uniformly, prevent conflicts of various transcription systems by enabling correct pronunciation of languages and develop specific symbol for each sound. In the transfer and adaptation processes of Turkish Folk Music Phonetic Notation System/TFMPNS to 
educational/doctrinal practices which was structured on the axis of International Phonetic Alphabet/IPA sounds whose existence and disponibility was registered on various fields by international standards, development of linguistic awareness skills (requirement of healthy vocal chord/technical ergonomics/correct sound production/behavior modifications/articulation/articulatory features of vowels/consonants/development of melodic memory/personal performance dialectic/notation and implementing on repertory etc.) must be analyzed with traditional relations in linguistic and musicological axis.

In order to transcript pathological speech properties which is not linguistic like phonological features of speck sounds/notation system (supra-segmental features/piece sound units like sound quality/level/height/emphasis/tonal/timbral variation ratios etc.) to define personal sound properties/differences/preferences/emotional variations developed depending on the phonetic characteristics based on individual source, to express alphabetical symbol usage and speech concept in terms of sound arrays, to show the acoustic patterns in speck analysis and to discuss the problems arising from the relationship between the note system and physical speech event depending on each other with regard to fractional meaning, it is necessary to perform formation/development processes of Turkish Folk Music Phonetic Notation System Phonotactical Probability Calculator Database/TFMPNS PPCD with the transfer/adaptation processes of Turkish Folk Music Phonetic Notation System Phonotactical Therapy Applications/TFMPNS PTA into education/doctrinal practices in the axis of Turkish Folk Music Phonetic Notation System Phonotactical Awareness Skills Development Processes/TFMPNS PASDP and Turkish Folk Music Phonetic Notation System Phonotactical Features/TFMPNS PF by configuring Turkish Folk Music Phonetic Notation System/TFMPNS phoneme/phoneme inventory/phonetic/allophonic notation system.

\section{References}

[1] Mehmet Avni Ozbek, Language and expression properties of Urfa songs, Istanbul University Social Sciences Institute of Turkish Language and Literature Department New Turkish Science Branch, (published PhD thesis), Istanbul/Turkey, pp. iii-338. 2010.

[2] Nurettin Demir, On variations in Turkish, Ankara University Language and History-Geography Department, Turcology Journal, vol. 17(2), pp. 93-106, 2010.

[3] Yücel Bicil and Gonca Demir, IPA Turca: Rule-based phonetic converter program/KTTFDP, TUBITAK National Electronics and Cryptology Research Institute of Multi-Media Technology Research and Development Laboratory, Gebze/Istanbul, 2012.

[4] Cetin Pekacar and Figen Guner-Dilek, International phonetic alphabet and dialect researches in Turkey, dialect research of Turkey Turkish workshop (25-30 march 2008 Sanliurfa), Ataturk Culture, Language and History Institute TLI Publications, vol. 989, Ankara, pp. 575-589, 2009.
[5] Iclal Ergenç, Speaking language and Turkish usage dictionary, Multilingual Foreign Language Publications Baskı Printing, Istanbul, pp. 1-496, 2002.

[6] IPA, Handbook of the international phonetic association: a guide to the use of the international phonetic alphabet, Cambridge University Press, Cambridge, 1999.

[7] Gonca Demir, Phonetic notation of local dialect features of Turkish folk music formed in language-music relationship axis, Istanbul Technical University Social Sciences Institute of Turkish Music Program, (published master's thesis, adviser: Assoc. Prof. Erol Parlak), Istanbul/Turkey, pp. v-294, 2011.

[8] Ruth Stone, Theory for ethnomusicology, Pearson Press, New Jersey, pp. 51-53, 2008.

[9] Lisa Davidson, Phonotactics and articulatory coordination interact in phonology: Evidence from nonnative production, Cognitive Science, vol. 30, pp. 837-862, 2006.

[10] L. Velleman Shelley, Phonotactic therapy, Seminars in Speech and Language, vol. 23(1), pp. 43-55, 2002.

[11] Ahmet Bican Ercilasun, Transcription signals that will be used for dialect researches, dialect research information fest, Ataturk Culture, Language and History Institute TLI Publications: vol. 697, Ankara, pp. 43-48, 1999.

[12] Mukim Sagır, Transcription in dialect studies, dialect research information fest, Ataturk Culture, Language and History Institute TLI Publications: vol. 697, Ankara, pp. 126-138, 1999.

[13] IPA, International phonetic association/IPA available from $<$ http://www.langsci.ucl.ac.uk/ipa/ipachart.html $>$ (access date: 14.11.2013).

[14] IPA, International phonetic alphabet/IPA chart 2008, available from $<$ http://www.langsci.ucl.ac.uk/ipa/extIPAChart2008.pdf $>$ ( access date: 14.11.2013).

[15] IPA, International phonetic alphabet/IPA number chart 2005, available from $<$ http://www.langsci.ucl.ac.uk/ipa/IPA_Number_chart_(C)200 5.pdf $>$ (access date: 14.11.2013).

[16] IPA, International phonetic alphabet/IPA unicode characters codes, available rom $<$ http://www.langsci.ucl.ac.uk/ipa/phonsymbol.pdf $>$ (access date: 14.11.2013).

[17] IPA, International phonetic alphabet/IPA X-SAMPA, available from <http://www.kreativekorp.com/miscpages/ipa/ipa-x.html> (access date: 14.11.2013).

[18] IPA, International phonetic alphabet/IPA sounds records, available from $<\mathrm{http}: / / \mathrm{www}$.langsci.ucl.ac.uk/ipa/sounds.html $>$ (access date: 14.11.2013).

[19] TLI, Turkish language institution Turkish audio dictionary/TLI TAD available from $<$ http://www.tdk.gov.tr/index.php?option=com seslissozluk\& view $=$ seslissozluk $>$ (access date: 14.11.2013).

[20] HEC, Higher education committee local thesis center, available from <https://tez.yok.gov.tr/UlusalTezMerkezi/> Tez No: 263098 (access date: 14.11.2013).

[21] TLI, Turkish language institution current Turkish dictionary/TLI CTD, available from $<$ http://www.tdk.gov.tr/index.php?option=com_gts\&view=gts $>$ (access date: 14.11.2013). 
[22] TLI, Turkish language institution big Turkish dictionary/TLI BTD, available from $<$ http://www.tdk.gov.tr/index.php?option=com bts\&view=bts $>$ (access date: 14.11.2013).

[23] TLI, Turkish language institution scanning dictionary/TLI SD, available from $<$ http://www.tdk.gov.tr/index.php?option=com_tarama\&view $=$ tarama $>$ (access date: 14.11.2013).

[24] TLI, Turkish language institution Turkey Turkish dialect dictionary/TLI TTDD, available from $<$ http://www.tdk.gov.tr/index.php?option=com_ttas\&view=tta s> (access date: 14.11.2013).

[25] TLI, Turkish language institution dictionary database/TLI DD, available from <http://www.tdk.gov.tr/> (access date: 14.11.2013).

[26] Kyle Gorman, Generative phonotactics, the University of Pennsylvania Linguistic Department, (published doctor of philosophy thesis), Pennsylvania, pp. 39-64, 2013.

[27] Tim D. Sherer, Prosodic phonotactics, The Graduate School of the University of Massachusetts Amherst Department of Linguistics, (published doctor of philosophy thesis), Amherst, pp. 1-65, 1994.

[28] Bruce Hayes and James White, Phonological naturalness and phonotactic learning, available from $<\mathrm{http} / / /$ www.linguistics.ucla.edu/people/hayes/PhonologicalN aturalness/> pp. 1-32, 2012. (access date: 14.11.2013).

[29] Buruce Hayes and Colin Wilson, A maximum entropy model of phonotactics and phonotactic learning,availablefrom<http://cogsci.jhu.edu/people/files/_pub s-Wilson/HayesWilsonMaximumEntropyPhonotactics.pdf $>$ pp. 1-67, 2007. (access date: 14.11.2013).

[30] Mahesh Radhakrishnan, Musicolinguistic artistry of niraval in carnatic vocal music, Australian National University/ANU Research Repository Proceedings of the 42nd Australian Linguistic Society Conference, pp. 422-463, 2011.

[31] Michael S. Vitevitch and Paul A. Luce, Web-based interface to calculate phonotactic probability for words and nonwords in English, Behavior Research Methods, Instruments \& Computers, vol. 36(3), pp. 481-487, 2004.

[32] Bruce Hayes, BLICK: A phonotactic probability calculator, available from $<\mathrm{http} / /$ www.linguistics.ucla.edu/people/hayes/BLICK/> pp. 1-11, 2012. (access date: 14.11.2013).

[33] Kenny L. Vaden, H. R. Halpin, and G. S. Hickok, IphOD: Irvine phonotactic online dictionary, version 2.0. [data file], available from <http://www.iphod.com> (access date: 14.11.2013).

[34] UCLA, Phonetic lab archive: Language database, available from <http://archive.phonetics.ucla.edu $>2009$. (access date: 14.11.2013).

[35] Frank Capodieci, Bruce Hayes, and Colin Wilson, UCLA: Manual: phonotactic learning program, available from $<\mathrm{http} / /$ www.linguistics.ucla.edu/people/hayes/Phonotactics/M anual.pdf $>$ pp. 1-17, 2009. (access date: 14.11.2013).

[36] Michael Vitevitch, PPC: Phonotactic probability calculator, available from $<$ http://www.people.ku.edu/ mvitevit/PhonoProbHome.html> pp. 481-487, 2004. (access date: 14.11.2013).

[37] Katarzyna Dziubalska-Kolaczyk, NP extension: B\&B phonotactics, Poznań Studies in Contemporary Linguistics, vol. 45(1), pp. 55-71, 2009.

[38] ANU, World phonotactics database, Australian National University Press, available rom $<$ http://phonotactics.anu.edu.au/index.php $>, 2013$. (access date: 14.11.2013).

[39] Merry A. Beckman, Benjamin Munsonb, and Jan Edwardsc, Methodological issues in the analysis of phonotactic probability effects in nonwords, ICPhS XVII, Hong Kong, pp. 300-303, 2011.

[40] IPA, International Phonetic Alphabet/IPA chart 2005, available from $<$ http://www.langsci.ucl.ac.uk/ipa/IPA_chart_(C)2005.pdf $>$ (access date: 14.11.2013).

[41] IPA, International Phonetic Alphabet/IPA fonts, available from $<\mathrm{http} / / / \mathrm{www}$.langsci.ucl.ac.uk/ipa/ipafonts.html $>$ (access date: 14.11.2013).

[42] Ahmet Caferoglu, Vowels and consonant changes of Anatolian dialects. Turkish language studies yearbook-belleten offprint from 1963-1964, Turkish Historical Society Printing House, Ankara, pp. 1-33, 1964-1965. 